\title{
Who is the sinner? The view of Karl Barth
}

\author{
F J van Zyl ${ }^{1}$ \\ Professor Emeritus: Department of Science of Religion \\ and Missiology \\ University of Pretoria
}

\begin{abstract}
This article focuses on Karl Barth's view of the human being as sinner. In accordance with his christological approach to all theological matters, the article aims to argue that Barth describes the image and character of the sinner as mirrored by the obedient suffering and vicarious death of Jesus Christ on the cross in the place of all sinners of all times - past, present and future. According to Barth, the price that God paid in surrendering God's only Son to such suffering indicates the enormous guilt and existence of every sinner. All human beings are hopelessly in debt and can only be delivered from sin through God's graceful remission of sin.
\end{abstract}

\section{WHO IS THE SINNER?}

The answer to this question will be threefold. Before discussing the answer to this question, however, a few preliminary comments must be made.

An answer must be given to the question of who and what is the human being who commits sin, who and what is the character of the person-of-sin. Here, too, the answer can be given with Christ in mind. According to teaching about Christ it became known, true and clear in him and in his resurrection from death that the Lord God, in order to reconcile the world to God, humbled God self by becoming a servant. Based on this Christological knowledge, the answer to the question posed is that the person-of-sin is the fallen human being, the one who fell to where God, Who cannot fall, humbled himself in Jesus Christ for the sake of humankind. This is humankind who exists down below where God sought him in Jesus Christ and placed himself as the sinner's equal. The human being is precisely that which Jesus Christ became

\footnotetext{
${ }^{1}$ Dr F J van Zyl is Professor Emeritus in the Department of Science of Religion and Missiology, at the Faculty of Theology, University of Pretoria. Prof Dr P J van der Merwe is responsible for the English version of the article.
} 
to be his Saviour, Helper and Redeemer: a servant, a slave, but not in the freedom of God, but as a poor prisoner; not in the glory in which God was, but in dire need, in boundless shame. Without being expressed, this answer encompasses at least three aspects of the fall of humankind, which will be discussed more extensively later.

Humankind's fall corresponds to its pride, indicating the essence of sin. According to the proverb, pride comes before a fall, but here humans in their pride came to a fall. Human beings fall while elevating themselves to heights to which they ought not to raise themselves. Human beings are dying because they want to take life for themselves, whereas they could have lived in peace had they wanted to receive it.

Furthermore, as regards the knowledge of the person-of-sin, one should not try to come to understanding independently of the revelation in the Word of God. Just as no one can see outside himself or herself and admit that he or she has sinned and continues to sin in pride, no one can see outside himself or herself and understand that he or she has actually fallen and is now living down below as a slave. What the Bible tells one about one's fall, will always be regarded as too dreadful and exaggerated from one's own experience and knowledge of life's depths. People's self-knowledge through which they acknowledge themselves to be people-of-sin, as the fallen, can only be true if they hear and believe God's Word, see, acknowledge and accept God's judgement over them, see and understand themselves in the light of this judgement. Only those who hear the living voice of the Gospel can see and understand themselves in this way. This Gospel is after all the Gospel about the Lord who, for the sinner's sake, humbled himself and in fact became a servant in humankind's place. Whoever hears the living voice of the Gospel, and only such a person, receives the answer to the question of who he or she really is. Everything said about humankind as sinners must be measured by this.

Another preliminary comment should be made about the fall of human beings. Firstly, a restrictive comment. No matter how the fall of humans is described, it cannot and may not be said that to God humans have become degenerate, forgotten and lost. It is true that humankind's fall encompasses all of this, that there is a chasm, that an empty space of the Void has arisen in humans' existence and amid the well-created world of God, to his dishonour and pain. However, God's positive will has nothing to do with the Void. It is true that humans have as it were become the brink of this precipice, and that they show the revolting reality of this chaos clearly and painfully enough. But even if their existence on the brink of the precipice is a reality, it does not mean that they have fallen from God's positive will and no longer exist to God. 
Seen from humans' perspective, they can indeed become Godless, but not from God's side, the God who created them and gave them life. (In scholarly language it is said that people can become relatively, but not ontologically Godless.) It is bad enough, however, that people can become relatively Godless. One cannot really withdraw oneself from God. My Godlessness cannot make God humanless. God does not stop being Creator, God, Lord of the Covenant of fallen humankind. In their fall, humans still remain God's creatures, bound by His covenant. Just as humans cannot create themselves, they cannot transform themselves, not for good nor for evil. Humans cannot change themselves into other beings and, as they are, they cannot destroy themselves. And as humans did not establish and founded the covenant, they cannot revoke it either. Only if one forfeits one's point of departure, namely that humans can be known solely by what happened to Jesus Christ, one can ascribe to humans an absolute Godlessness. Humankind did not fall lower than the level where God humbled God self in Jesus Christ. But God did not become diabolical or nullified in Jesus Christ. God's Word became flesh, became part of our corrupt being. Corruption does not mean changing humans into completely different beings, however, because God's atonement would then be unfounded. The prodigal son among the swine found he was still in the same world where his father's home stood (although at a distance). Through the fall of humans, God's covenant with them was completely and irreparably broken but this did not invalidate, did not revoke, did not erase the covenant as God's omnipotent work of mercy and grace. To the contrary, God maintains God's eternal covenant, restores and renews it while God applies God self to fallen humanity. God will not be diverted by sin from the resolve to say yes to humankind. In fact, when God reconciles humankind with God self, God stands by the original yes to humankind. This is a yes of tremendous and profound rejection of humankind's sin and fallen existence, a yes of God's judgmental mercy, a yes of a death sentence and its execution. It is and remains God's yes, God's covenantal will which is not nullified by the sin and fall of humans. In carrying out this yes, God suffers through human beings, with human beings and for human beings, even taking their death upon God self. However, God takes it upon God self to vanquish it, to live authentically as God by dying as a human. If one says that humankind in its fall is absolutely Godless, that sinfulness is its essence, that humankind is the image of the devil, one would have to include the allegation that the living God who committed God self to humankind and became one with it, not only died but was also condemned to eternal death. However, death did not prevail over God, on the contrary God vanquished death while taking it upon God self and, in God's Son, died with us and for us. 
In addition to everything said in the preliminary comments, it does not really amount to a mitigation but rather a honing of the knowledge of humankind as sinners. It is the dreadfulness of the condition in which sinners find themselves, that they are in no way dismissed from the domain of the living God, from God's yes and God's merciful grace, not from the relationship of Creator to creatures, and not from God's covenant with them. They "may" indeed fall and become unfaithful to God. But as Psalm 139 aptly describes, humans cannot escape from God. That God has always said yes to humans means that those who do not want to hear it and do not want to rejoice in it, must hear God's yes as an annihilating no. God can also have God's yes heard as a no. That God's grace is directed to a human means that those who despise and dislike it and do not want to live by it, will be struck by God's wrath and doom. If we treat God, who is our friend, as an enemy then we will have God as an enemy.

\section{WHAT DOES A SINNER LOOK LIKE?}

We now come to the real substance of this matter, namely how we measure up when we look into the mirror of the Son of God's obedience. This concerns human beings who have fallen in sin, to whom God bowed down in Jesus Christ, stood next to them and became solidary and equal to them. The question is what burden God did not need to bear did God voluntarily take upon God self, bore it triumphantly and away from us? Our corruptness cannot after all be another, not a larger or a smaller, burden than that for which Jesus Christ suffered and died on the cross until its ending. The question is what is this corruptness that Jesus Christ, the living and judgmental Word of God, reveals to us?

This question is answered with three doctrinal statements, the first of which is as follows: because that Word - namely Jesus Christ as living Word of God - is the Word of divine forgiveness addressed to humankind, it was decided that the corruptness out of which it calls and tears human beings, lies in humankind's being a debtor to God, a debtor unable to pay; whom God can only forgive because God does not expect any settlement from this debtor, because God deems him or her unable to settle the debt. Even more, because any other settlement, except for God's forgiveness, would not be right. God does not forgive without reason, senselessly, by chance or lightheartedly, or solely because humankind is unable to repay. God forgives before everything and decisively, because this alone can end violation of justice and restore the disturbed order resulting from humankind's sin and debt. From this we can try to judge how matters stand with humankind's guilt and debt. 
Debt is the shortfall towards a commitment and an obligation, where one causes damage to the person to whom one has an obligation, because the relationship with that person has become disturbed. The guilty party is the cause of everything and is liable for the damage he or she caused the other person. The sin of human pride in the relationship with God is such a shortfall and as such is humankind's debt and guilt. Humans should not have committed this sin. We have already seen that sin makes no sense and is groundless. One can only determine that human beings commit it. It is their doing and they are accountable for it. The submissiveness of faith and obedience required of human beings as creatures of God and God's allies remain in abeyance, as do the freedom and possibilities with which God empowered them. A vacuum arises in the existence of the human beings who have been created well by God. Through this, God's plan is thwarted, God's honour is diminished. God bound God self too intimately to humans for this negligence on our part not to grieve and offend God. Humans are solely accountable for this state of affairs. They affront God and are disturbers. They are also accountable for the fact that a clouding and disruption, indeed a darkening and confusion, have entered the relationship between them and God. Humans are accountable for the fact that God can no longer be what God as Creator and Lord ought to be for them, that God's yes to them has now become shrouded in a no, that God's love has now become the consuming fire of God's wrath. Humans are accountable for the chasm and vacuum that arose from the Void's having worked through and caused chaos in the entire good creation of God. Because humans have fallen short in their obligation to God, they have opened the sluice gates of chaos and confusion. This, then, is humankind's guilt in general, the charge against them.

But perhaps the matter should be examined slightly more thoroughly. We have after all determined the following: because God's reaction in terminating the situation arising from the debt and guilt of humans consisted in God's forgiveness, and because in sacrificing God's Son in our stead God made God self known as the God who forgives us our sins, a decision was taken on two matters: firstly that humans are insolvent debtors who cannot pay their debt, and secondly that forgiveness is the only sufficient, correct and effective way God's reaction can be fulfilled and eventually was fulfilled. Through God's forgiveness our negligence and arrears toward God are made good again, the disturbed relationship between God and us is restored again, chaos is forced back and the chasm closed. The question is how human beings' debt and guilt should be understood in view of the fact that God meets them in precisely this way, as the God who forgives all their sins. 
It is clear that the God who meets the indebted humans as the God who forgives their sins, is essentially a merciful and compassionate God, omnipotent and holy, Creator of heaven and earth, Lord of the covenant with humankind. It is this God of whom the Scriptures testify that where sin was multiplied, God's mercy and grace became even more bountiful (Rm 5:20) and that this contrast between sin and grace is precisely where God's forgiveness, God's iron sceptre, God's weapon, God's sword of justice and acquittal became understood. The one who judges and rules in this way is God in God's immutable existence and being, and no one else. The way in which humans are obligated to God must correspond with this existence and being. Humans are subject to God, not as insignificant people are to one who far surpasses them, not as the finite to the infinite. This is also true, but the relationship to God has another content. The freedom, infiniteness and supremacy of God, that place human beings under an obligation to God, are the freedom, infiniteness and superiority of God's grace towards humankind. The restrictiveness, finiteness and insignificance of humans, and for that reason their subjection to God, are the restrictiveness, finiteness and insignificance of people who undeservedly, without doing anything from their side and without really understanding, can rejoice at being the object of God's merciful condescension. One is bound and obligated to nothing else but to accept this merciful grace of God and to live in the joy and the freedom accompanying it and corresponding to it, and just to be grateful in it. Indeed, the yoke is easy to bear and the burden is light (Mt 11:30). This is not too much to ask. Here God's demand is permeated with the character of concession, nothing out of the ordinary is expected here, but only that you will be what you are, someone who is loved by God, and that you will confess on your own initiative that God approached you first and voluntarily. Neither can there be any dread of the high majesty of God here, nor does it make sense that human beings will withdraw from God because their own existence differs too greatly from that of God. After all, you should not in fact seek and create this relationship with the high God, because it is wide open to you and was created by the high God self, who differs so endlessly from you. Truly, we cannot and may not let our pride come in the way since we do not have the least grounds or slightest reason for this.

In fact, we become and are guilty because we conduct ourselves as sinners in this relationship with God, fall short toward God, diminish God's honour, disturb God's order. This makes our pride preposterous and unforgivable, and characterises it as frivolous and nullifying. It may be clear from this why, as a person-of-sin, once I have recognised myself like this, I can only be terrified of myself. I am like someone who finds himself on a steep 
slope and can only fear for the worst. It is obvious from this that the slightest thought of and step in the direction of such pride amount to transgression that can never be restored. And now, God's Word does not charge us with this or that single word, deed or thought, but accuses us of conducting our whole lives on the basis of pride, in fact we are rooted from beginning to end in this soil. The Word accuses us of being guilty always and everywhere, of responding to God's grace not with corresponding gratitude but in some form of our pathetic pride. Because the order where we stand is God's merciful ordering which ensures that no one has any grounds or reason for such haughty deeds, we place ourselves in the empty and bottomless void when we shatter this order. We would only be lost if, in spite of our transgression, God did not stabilise, restore and maintain this order for us too.

The extent of this human guilt and debt must be examined more closely. If we want to spurn being God's beloved and refuse to acknowledge God as a merciful God, then we place ourselves under God's doom, under God's no. If you want to contradict the good will of God towards you, you as contradictor must endure that the will of God will also contradict you. This is the wrath of God. It is God's averseness towards everything that He did not want, does not want and never will want. It is God's dominion over everything on God's left hand side. Then God becomes human beings enemy, meets them in the foreign stature of the wrathful God.

Now it is also clear why you cannot settle your debt yourself, you cannot remove yourself from the threatened region of rejection, cannot in any way achieve your reconciliation with God. Humans have sinned towards God's grace, and because they do not have God's mercy at their disposal, their attempt to save themselves will only augment their sin of pride. God's grace is free of charge, that is why humans cannot lay any claim to it, nor to the way it is offered to them. If God wants to be merciful to you in judgement and doom, you cannot want to skip this page, you must read what is written on it. Only one thing remains for you, and that is to accept in faith the mercy and grace of God in judgement and doom. Only in this way can we pray: forgive us our guilt. This prayer is the admission that you cannot forgive your sins yourself, cannot be merciful to yourself, even when you want to involve God in it. It would just mean a renewal of our pretension and high-handedness that is the real reason for our culpability before God.

And so the end of our considerations has brought us back to their beginning, to the way and the work of God, to God's forgiveness, God's acquittal. God's way and work with a view to human beings, to their guilt and debt reveal how matters stand with the latter, how heavy and huge it is. It also becomes clear by the fact that the execution of Divine wrath and doom, and 
the Divine acquittal, consist precisely in the surrendering of God's Son for us and thus in his free and unconditional forgiving us our sins. Committing sin means doing what only this God, and only if God proves and reveals God self as the merciful, can redeem. So great is the weight of sin.

The question of human corruption is answered as follows with a second doctrinal statement: because Jesus Christ died to atone for every human in his or her particular existence and condition, it was decided that human corruption is radical and total. This means that the sinful change takes place in the depth and centre of human existence, in the human heart and that the condition of sin emanating from it affects the whole human being, without excluding any aspects or particularities.

The living Word of God does not offer humanity teaching and rules aimed at only certain aspects of their existence. It enlightens totally and claims them completely. The content of this Word, namely the reconciliation that takes place in Jesus Christ, does not exist in a partial change and improvement in your knowledge and attitude. It entails a total change in your situation, and a return to God from whom you became alienated in your pride. It is therefore humans themselves, their hearts, and starting out from this centre of human existence, the whole of humanhood, who are involved in this alienation from God and must exist in alienation. This is what their corruption amounts to, in which God finds and recognises them, in which God addresses and adopts them. We are what we do and do what we are. And for this reason, we live in this vicious circle of doing and existing in this turning away and alienation from God, back and forth, in and out of sin.

As we have already seen, people do not stop being human beings in spite of their total sinfulness. They did not forfeit their nature which was created well, and in its place get an evil nature. The Bible accuses human beings from head to toe, but does not dispute their full and immutable humanness, nor the possession and use of their God-given capabilities. According to Genesis 1:27, God created humans as God's representative, in God's image God created them, man and woman God created them. In Barth's opinion, especially with a view to the last part of this Biblical verse, the likeness of humans to God should be understood in terms of shared humanity, in terms of fellowship. Barth concludes from this that there can be no question of a loss of this image, because even as a sinner, a human being is still a man with his wife (or vice versa) and a human with fellow humans. Nor can human beings resign from the covenant, even if they wanted to do so and even if they deserve to be cast out of it. Human sinfulness is far more serious than the loss of or damage to their good nature. It means that in their good nature, and within the covenant with God, they place themselves at the service of evil and 
now have to live in it. It is a flagrant contradiction that in the good and as the good, humans became Godless and fell to nothing in their pride. As God's chosen ally, humankind is now threatened by God's rejection, with eternal death, with perdition. In this contradiction humans cannot be justified, they do what they are and they are what they do.

Nor can there be any question of a remnant or kernel of what is good. The human being cannot be distanced from his or her sin nor can sin be objectified. The immense gravity of the situation consists in the fact that the one entire human being whom God created well, and leads, maintains and rules, and which is to God the same as the first day, and which does not stop recognising itself as God's ally, that this same human being chosen by God and fully equipped for God's service, turns away from God and is now what this alienation brought about: wrong, guilty, God's enemy, the object of God's wrath because the human race did not want to let itself take pleasure in being the object of God's mercy and grace. How could it be possible to isolate a remnant of what is good from the total human being? What might possibly be termed good could only be the good and merciful will of God which is active in and over the good human nature: the existence of humanity before God as object of grace even in the configuration of God's judgement. What we are before God, we are without remnant, without part or parcel, totally and decisively so. There cannot be any question of an untouched kernel of good in humans. The Word of God accuses human beings of being sinful to their deepest core, in their hearts. In their sinful pride they want to be God and Lord themselves, to rule over good and evil themselves and be their own helpers. In all of this, humans hate God and their neighbours.

This obviously means that where humankind's transgression and corruption are concerned, there never was a distant time when humankind was no transgressor and therefore not guilty. To concur with a great scholar, humans live by an erroneous principle, by radical evil, to which they are indeed not identical but with which they associate themselves and to which they bind themselves. Humans transgress because they have always and invariably come from the transgression, in fact their existence as such reflects this continued transgression. Never have human beings not been guilty of pride. They are and have always been proud in their own deeds, in their existence. Not only do humans sin, they are sinners. The accusation against them, in as far as their transgressions are concerned, may elicit discussion and argument, but not as it concerns themselves. This is why Jesus did not die for them to remove this or that sin, but for their return to God, to remove their false point of departure so that they could be born anew of the Spirit and become new human beings with a new origin and beginning. If this is true, 
then it is also true that human beings were always unreconciled people without Jesus, originally and from the beginning they were flesh, sinful, the former people who always hated God and their neighbours and therefore children of wrath.

Since this is so, there is also no exception, no area of pardon with regard to human beings' transgression and corruption, where they are not guilty and wrong. They are wrong and guilty in every respect toward God and they are in arrears. As subjects they are not good trees, so they cannot bear good fruit. Because their pride is radical and fundamental, it is also allencompassing and therefore everything they think, say and do bears its sinful stamp. Because human beings are not partially but wholly and completely flesh, all their deeds, feelings and utterances have a fleshly character.

Nor is there a neutral area where human beings in all their actions or existence stand alone and by themselves, on the other side of good and evil, of obedience and disobedience. They always stand face to face with God and their fellow humans in what they think, say and do. There is no area or time in which God's grace and commandment has not been addressed to humans, and no area or hour without decisions. Since human beings are in their nature evil and sinful, disobedience marks every hour and area. Although God's commandment always comes to every human in an unique shape and form, no one's response will be uniform and only by approximation and with the most serious reservations identifiable as transgression and sin, if adjudged in accordance with human norms and standards. Only God alone Who knows your heart, not you yourself, nor your fellow humans, is your prosecutor and judge. Because God's Word accuses every human being of having a fleshly and evil heart, there can be no doubt that every person's decisions in all areas and times will have the character of false decisions and false responses to God's commandment. So no one can boast of what he or she achieved, but must instead feel ashamed. Also, when people are pleased with achievements in the realisation of their good nature, as judged in their own eyes and in the eyes of others, they are nevertheless sold into sin with everything they are, and their good deeds are also in the service of evil.

It would be a great mistake to regard what has just been determined as pessimistic exaggeration. At some time or other you will ask yourself: where do I stand? Who am I? What is the state of my heart? There are even more questions: what was the state of affairs at some or other point in time or circumstance of my life with regard to my responsibility to God and God's commandment: Did I conduct my responsibilities with a pure and honest consciousness? Did I really seriously try to discern the will of God, to search for what is good, acceptable and perfect to God (Rm 12:2)? Did I really act 
with determination and decisively whenever I responded to what I recognised as right? Were my deeds in accordance with this? The possibility of denying and contesting that the human being as such is a sinner and calling it an exaggeration, means only one thing; that all the set questions are not known, or their full gravity is not acknowledged. We must hear and understand all the questions as ultimately boiling down to the one single question: how do I stand before God? If one understands this question in its full gravity, there can be no war of words about the doctrine that humankind as a whole is guilty and sinful. It transcends the contrast between an over-optimistic and overpessimistic human self-judgement, namely what God in the Word of God's grace has to say to us.

If the decision comes from that side, it is also a gross error to think that the doctrine of our total sinfulness lends itself to paralysing and even abolishing our concrete human knowledge of sin, the consciousness of our concrete responsibility, and the courage of concrete resistance to evil, in favour of a sterile detachment and resignation to any hope of a human existence free of sin and guilt. Precisely for this reason it does not add up, because this standpoint can only be considered and expressed in the concrete knowledge and responsibility of someone who has heard the Word of God and God's commands, precisely as acknowledgement of the divine judgement and doom. Precisely because he or she acknowledges it, it cannot be a submissive doctrine, but it becomes a concrete appeal: deliver us from Evil. Human beings who appeal like this cannot be content with their corruption, but desire its complete removal. Moreover, as concrete acknowledgement of God's judgement and doom, such realisation amounts to a concrete confession of God whose deed has not been in vain whereas everything we do is undoubtedly in vain, even in the best of lives. It is the confession of God who helps where all human self-help can only confirm and magnify evil. Since this acknowledgement and confession have their basis in God, the confession cannot be non-committal, acquiescent, hopeless and passive. Whoever is willing and able to make this confession holds firmly to God's compassion, accepts his or her inequality and regards him or herself as powerless compared to God's superior power. Because such people have a clear vision of this overwhelming glory, they cannot and may not make any boasts about themselves. But while and because they wait solely on the Lord, they will fly with the wings of eagles and with a resilience about which those who criticise the doctrine that humankind is totally and fundamentally sinful and guilty, do not have the slightest idea.

The third doctrinal statement as answer to the question of humankind's corruption is derived from Romans 11:32: since God wanted to and did take 
pity on all humans in God's surrender of Jesus Christ, it was decided that God had previously "included" all of them in the "disobedience". Here "included" means placing them under a valid, indubitable, incontestable and irrefutable judgement and sentence, with all the consequences that might emanate from this. God's compassion corresponds with God's inclusion. Those on whom God wanted to take pity are the same as those whom He previously included in the judgement and sentence. This is said of all people.

This concerns two large contexts encompassing all people in accordance with God's will and stipulation. The one encompasses everyone in a prospective future existence, those to whom God's pity has been granted when God's Son went into foreign parts for them. The other encompasses in retrospect all those who existed in the past. This is the contiguity of "inclusion": those whom God assembled, considered, addressed and treated, with a view to this inclusion, who all went their own way in their pride where and because of their pride they all had to suffer downfall. It is the contiguity of all those who belong to a state of disobedience, according to the judgement of God's Word. They are those who were existing in foreign parts and yet sought by God through God's Son to call and bring them back to the fatherland. These two contiguities meet and cross each other in all people's present, and the decision about all of them falls in the Gospel of Jesus Christ, which was revealed and announced to them and heard by them, the Gospel that they believed and understood, or did not believe and did not comprehend. The words of the apostle Paul and the confession of the church both read like this, provisionally in this (whole) world: God (the Father) rescued us from the domain of darkness and brought us into the kingdom of God's Son whom God loves (Col 1:13). The "power of the darkness" is exactly the same as being included under disobedience, the context in which God's due judgement had previously put all of us together. Those who have their future in the kingdom of Jesus, have their past in the dominion of darkness. This concept needs to be expanded further.

Everything said so far about human beings' sin, pride and fall dealt with their past, their existence that lay behind them. In Jesus Christ's resurrection from death God reveals as it were afterwards who has been vanquished and destroyed in Jesus' death. It is the person-of-sin. An attempt was made to recognise the person of disobedience where he or she was destroyed, namely in the mirror of the obedience of the Son of God. The decisive thing that can be said about this person, is that he or she was annihilated, belong to the past and no longer has a future. Had we always been that person, or had we become that person again, and if we were to be that person in future, then the decisive thing that could be said about us is that we can and will only be as 
the already annihilated, in a ridiculous representation of our own past as our own phantom. It is after all a contradiction that the person-of-sin who was killed and died on the cross at Calvary can still be alive. Paul motivates the impossibility of still persisting in sin by referring to Romans 6:9: "We know that Christ, once raised from the dead, is never to die again; He is no longer under the dominion of death. For in dying as He dies, He died to sin, once for all, and in living as He lives, He lives to God. In the same way you must regard yourselves as dead to sin and alive to God, in union with Christ Jesus" (The New English Bible, 1970). There is no longer any freedom to commit sin anew and again. The dominion of darkness lies behind us. We have all been released from that prison.

To know this prison well in which we were included, is not a frivolous matter because it would not have been possible to look ahead with grateful resolve or to go forward without knowing what lies behind us. If we listen once more to Romans 11:32, we hear that everyone is included in the disobedience. The radicality and totality of sin and guilt dealt with in the previous main section, corresponds with the universality of the inclusion. Though the Bible does not use the word "humanity", the word "everyone" can justifiably be accepted as a concept of equal value and as equivalent. Not merely a few people, but everyone, the whole of humankind, is sinful and commits sin. "For all alike have sinned, and are deprived of the divine splendour" (Rm 3:23). God's judgement and doom always strike one and all. The individual is part of the whole community. If you may acknowledge your own sin in the light of God's word of grace, then you recognise in yourself the whole of humanity as sinful and guilty before God. What happened at Calvary took place not only for me, but for us all. For this reason we pray: Our Father, forgive us our transgressions. After Israel and the [different] peoples became one people, this "we" became boundless. From the Gospel alone, the idea of a humanity could have been accepted as a Christian concept, in the sense that God's grace is directed to the whole and sum total of all people, since all of them are sinful and guilty before God.

Just as the Bible does not use the term "humanity", it does not know the concept "history". But the word "everyone" also suggests what we mean by the concept "history".

The Bible is a history book par excellence as testimony to a special history, namely the testimony of God's presence, acts and revelation as purely an earthly human history. This particular history concerns God's will, word and work among people. This history does not concern the origins, contexts, developments, mergers and divisions, goals and new beginnings of human will and enterprise, nor their motives, practices and expectations of the future. 
The Bible concerns this history solely in so far as it becomes visible in the light cast by that other human history. Typical of this human history is that it has been detached from God's will and word and work, and as such it is already based on erroneous, sinful human thought, an invention of human pride. Such a history is no illusion because it does in fact exist in the world. Knowledge of human sin and guilt in the light of the Word of grace implies that this history based on human pride follows the course of God's judgement. The world's history is included in disobedience. This does not mean that it has been wrested away from God's governance and placed under the rulership of fate or the devil. Nor has the divine governance of world history ceased to be the governance of God who was, is and will be beneficent to human beings. The history of the world that was created by God in Jesus Christ and is aimed at him, Jesus Christ, cannot through the fall of humankind cease to have its centre and purpose in God. From this centre, God cannot say yes to the change and erroneousness, only no. All those who hear the word of grace from this centre cannot pretend that they have not heard it, cannot dilute it, cannot declare it different, and cannot forget it. Deeply hidden under this no, God's yes is concealed from these poor and wrong people who act and suffer as the subjects of this history. However, it is also God's no to the erroneousness of this world history.

We may not forget that human beings did not lose their good nature with all their capabilities by their own change and by the judgement of God pronounced over them. Astounding plans, awe-inspiring effort and wonderful results and achievements, masterpieces of competence and virtue, are possible and real within this inclusion in disobedience. Even if these seem to compare favourably to many of our less illustrious, dangerous and corrupt human acts, they still stand under the same designation of sin, disobedience and pride and therefore under God's doom. In any case, it is foolishness to conclude from the progress made in one particular field, for example technology, that this also means progress for humanity. Actually the stagnation and perhaps deterioration of humans are more typical than their progress. Their lives display a surprising monotony, the monotony of their sinful pride in which early on they led a life of suffering for themselves and their neighbours, and so it will be until the end. This is the meaning of world history's inclusion in disobedience.

The Bible classifies human beings and world history under the name "Adam". Adam simply means a man. As bearer of this name, which typifies the existence and being of all creatures equal to him, he appears in the story of Genesis as the man who has his existence thanks directly to the Creator's will, and to the word and work of God, and as such he is the first, the 
primordial man. Adam the transgressor is the title God placed over the world's history. His name explains the sum of the history of the humanity that relinquished God because of their pride. It is the explanation of the sense nonsense - and meaning of this world history. It is Adam's history, because it begins with his history and in its course always corresponds with his history, is repeated in innumerable variations, endless repetitions of a small piece of Eden.

There never was a Golden Age. It is senseless to long for something like it. Primordial humans were simultaneously the primordial sinners. According to the Old Testament, world history began in this way, that is why it places Adam at the head of the history of human will and acts. Also, after this the Old Testament recounts that everything always began in this way: immediately after experiencing of God's goodness, it begins with people's thoughts, words and works, stupidity and evil. It is the structure of God's history with all peoples. God knows all people and groups of people. "The Lord looks down from heaven on all mankind to see if any act wisely, if any seek out God. But all are disloyal, all are rotten to the core; not one does any thing good, no, not even one" (Ps 14:2, 3). In the knowledge of God who sees through all people of all times, they are all once more and still Adam, who do what he first did.

Who is Adam? The great nameless one who was the ancestor of the human generation? There is no doubt that the Biblical tradition also wants to see him and refer to him in this way, but Biblical interest in him lies more in what he did. So was he a specially burdened sinner? After all, his transgression was so slight compared with the transgressions of others reported in the Old Testament, some of them very holy people, that one hesitates to point him out as the first among equals. In the unnoticeable manner of the beginner, everyone who came after him commits the same transgression which we all commit, no matter whether it is weightier or lighter, more visible or less visible. Adam was completely ordinary, as we all are, a person-of-sin. In so far as he was a beginner, he can also be mentioned as first among equals. However, he did not leave as a legacy that we have to be like him. He did not poison us and make us sickly. Nor is what has been done after him, been done as the fatal imitation of an irresistibly detrimental example which his act set for his descendants. No one needs to be Adam over and over again. We are all him on our own responsibility and of our own free will. Though Adam's guilt is equivalent to ours, his sin is no excuse for ours and ours is no excuse for his. He and we are struck equally and with no possibility of blaming anything or anyone else by God's Word and judgement. The only difference is that he was and did the same as we all are and do, at 
the inception of history and was therefore the first to be struck by God's Word and judgement as an example for all who came after him. Who are these others and in what relationship do they stand to Adam, those who came after him? The Bible certainly envisaged that they are his physical descendants. How did it come about that they became equal to him in the act of his transgression as well? If we accept the sin among us and in Adam as a human decision and act, and that sinfulness cannot be regarded as a legacy to successive generations, there is nothing else to say but that the others who came after Adam are those who are represented in his person and deed. They are those whose will was correctly interpreted in advance and was expressed as erroneous will. Stated differently, they are those whose free will, acts and omissions, the realisation and actualisation of their human nature, which is in itself good, in fact follow the erroneous order that had already become visible in the person and deed of Adam, This was in accordance with prophetic testimony: just as it was at the beginning of the great history of the world, it became characteristic of the persons and deeds of everyone who came after him. We must see ourselves, humanity and world history in him. Adam is not the fate that God cast on us. Adam is the truth about us, known and said by God. The association between him and us cannot be based on or shown by worldly facts. God determined it. God's Word gives humankind this name, and world history this title. God's Word condemns his and our disobedience. God's Word forbids us to dream of a previous golden age in the remote past, or of a real advance in the Adamitic humanity and history, or of a future in world history, and forbids us to place our hope in anything else but in the reconciliation that took place in Jesus Christ.

We have heard that Adam's sin is the title over the existence of all people, that in his person God judged and condemned all of us, the whole of humanity, the entire world history: all are included in disobedience. The question now is why and in how far we must hear and respect it as the Word of God. A brief glance at Romans 5:12-21 may give us an answer. Who is Adam to Paul? Verse 12 states that Adam was the one person through whom sin came into the world and through sin, death, and so death penetrated to all people because all had sinned. It is "Adam" as title over all people and every person, as the representative and rule for all people. Paul also knows and respects this title. God set it over world history. Whence did he find this truth or did it find him? Without doubting the testimony in Genesis 3, the question is how this part could have become the authoritative Word of God to him in order to understand humanity and world history. In that first and lonely man who existed and was created directly by God, in that unmistakable characteristic sinner and guilty party at the head of the whole of humanity, that dark 
representative of all of us who would bear his name after him - all at once Paul recognised a completely different One. One Who also came directly from God, not as God's creature, but as the Son of God, even also God. He, too, is the representative of all those others, except that he is not equal to them, that he is not the first among equals who stand in the same row, but he went to stand in front of them as leader and reconciliatory in his obedience, covered their sin of disobedience and justified them before God: As one transgression led to the condemnation of all people, so did one act of obedience led to acquittal and life for everyone. As many became sinners through the disobedience of one man, so too will many be acquitted through the obedience of the one Man.

With regard to this verdict of the apostle about the relationship between Adam and Christ, some speak of the Adam-Christ parallel. Nevertheless, there cannot be any doubt that to Paul, Christ as primordial image should have first place and Adam, as a type or model of the One who would come, (14) the second place. Adam is the prefigure or shadow of Jesus Christ. He saw Jesus Christ first and then Adam. This means that he recognised Jesus in Adam, as in a photographic negative. In the unjust at the head of the old humanity he recognised the Just at the head of the new humanity. For precisely this reason, the idea of a parallel in this case remains problematic.

The line of Adam with all the numerous people included in his disobedience does not run independently along the line of Christ in whose obedience God wanted to and did take pity on many. As far as the external formal aspect is concerned, the line of Adam can be compared with the line from Christ, but in essence they cannot be compared. This is similar to comparing a rainbow with the sun: the rainbow, Adam's line, merely reflects back the sun, Christ's line. Without this sun it disappears. In complete inequality, not in balance, the human transgressions in Adam's act (here) are in contrast with the grace, the free gift of acquittal and life in the person of Christ (there), and so too the fate and destiny of all people here and their destiny and fate there. Here one must think of the words of the prophet: "On the impulse of a moment I forsook you, but with tender affection I will bring you home again. In sudden anger I hid my face from you for a moment; but now I have pitied you with a love which never fails, says the Lord who ransoms you" (Is 54:7; Ps 30:5, 12).

It is nevertheless clear who and what the first is and who and what the second is. Also, as Jesus Christ is called the last Adam in 1 Corinthians 15:45, this does not mean that he, in relation to the first Adam of Genesis 3, is the second, but that he himself is the actual and first Adam, the person who reveals the first Adam as a prefigure. From thence, as seen from Jesus Christ, 
the last Adam, that first one had existence and permanence for Paul. Paul hears in what is said about the first Adam, that which applies and must apply to him and all people: on the other side of the threshold over which Jesus Christ and with him every person stepped, he hears in him his sentence and that of all people as God's Word, the sentence on the person-of-sin against which no higher appeal is possible. This is the person who was every person and who no one longer is, after God with the same comprehensive grace took pity on everyone whom God formerly included in his judgement of disobedience.

\section{Works consulted}

Barth, K 1947. Der Römerbrief. Zürich: Evagelischer Verlag.

Barth, K 1953. Kirchliche Dogmatik, Band IVII (60). Zürich: Evagelischer Verlag. Noordmans, O 1939. Geestelyke perspectieven. Amsterdam: Hänssler.

The New English Bible with the Apocrypha 1970. First published by Oxford University Press and Cambridge University Press. Middlesex, England: Penguin Books. 